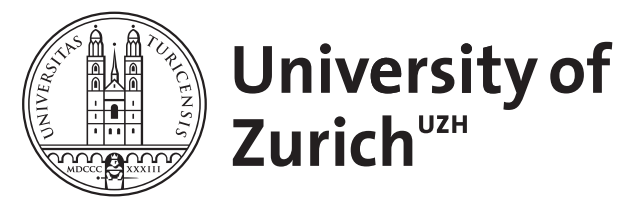

\title{
The Old English dry-point glosses
}

\author{
Nievergelt, Andreas
}

\begin{abstract}
The Old English dry-point glosses are a difficult but important material. The pertinent research has been neglected over the last years. This paper attempts to show the desiderata in this field: a large number of known dry-point entries in Anglo-Saxon manuscripts still need deciphering and editing. Moreover many manuscripts have not yet been examined systematically. Therefore it is necessary to reconsider the existing research on Old English scratched glosses. This paper gives an overview of the Old English dry-point tradition and of the current state of research and points out how to revive the study of Old English dry-point glossography.
\end{abstract}

DOI: https://doi.org/10.1515/9783110630961-009

Posted at the Zurich Open Repository and Archive, University of Zurich ZORA URL: https://doi.org/10.5167/uzh-184617

Book Section

Published Version

Originally published at:

Nievergelt, Andreas (2019). The Old English dry-point glosses. In: Lenker, Ursula; Kornexl, Lucia. Anglo-Saxon Micro-Texts. Berlin, Boston: De Gruyter, 161-173.

DOI: https://doi.org/10.1515/9783110630961-009 


\title{
Andreas Nievergelt The Old English Dry-Point Glosses
}

\begin{abstract}
The Old English dry-point glosses are a difficult but important material. The pertinent research has been neglected over the last years. This paper attempts to show the desiderata in this field: a large number of known dry-point entries in Anglo-Saxon manuscripts still need deciphering and editing. Moreover many manuscripts have not yet been examined systematically. Therefore it is necessary to reconsider the existing research on Old English scratched glosses. This paper gives an overview of the Old English dry-point tradition and of the current state of research and points out how to revive the study of Old English dry-point glossography.
\end{abstract}

\section{Introduction}

Old English preserved in medieval manuscripts was written not only with pen and ink, but also without any colouring matter. Many such entries may have been written with a stylus. The phenomenon is particularly well-known in glosses. In literature on Anglo-Saxon material, such glosses are called 'dry-point glosses' or 'scratched glosses', the latter term predominating in older research publications. The new terms 'stylus glosses' and 'stylus-glossed manuscript', used in recent studies and in Far Eastern glossology, seem to have been borrowed from German 'Griffelglossen'.

Dry-point glosses are difficult to find and to decipher. Search and examination require much time and patience, and many readings remain problematic due to the difficulty of identifying and interpreting them. Today, however, there is no doubt that dry-point glosses form a relevant and a highly interesting corpus. They certainly are an indispensable complement to our knowledge in the field of writing in the Middle Ages. Recent research has shown that glossing with a stylus constitutes a section of its own within the study of medieval writing. In scratched glosses a monastic literacy comes to light that also took place outside

1 Cf. for example Murdoch (1983: 26), where the German term is used in an English text: "Such Griffel-Glossen ('stylus-glosses') only become visible when [...]”. Cf. also Studer-Joho (2017: 26 n. 15). For the term in Far Eastern glossology, see Whitman et al. (2010: 11).

Andreas Nievergelt, University of Zurich

https://doi.org/10.1515/9783110630961-009 
of the scriptorium. All that is hidden behind our fair copies is spelled out here: personal efforts of text comprehension, grammatical analysis and translation by medieval scholars as well as preliminary work of glossators. Therefore those entries that are English form a special pragmatic section of Old English microtexts. ${ }^{2}$ Dry-point glosses are of crucial importance to the research in historical vernacular languages such as Old Irish, Old English, Old Saxon, Old High German and Old Slavic. ${ }^{3}$ The reasons for this are that dry-point glosses often represent ancient witnesses and can furthermore be taken as original evidence. Moreover, they constitute the main source for new-found lexical material. This is especially true for Old English.

This paper pursues three main goals: first, I will give a brief overview of the Old English dry-point tradition. Secondly, I will look at the current state of research, embodied in a new catalogue of the relevant manuscripts, the just published doctoral thesis of Dieter Studer-Joho (2017). I repeatedly refer to it throughout the paper. Finally, I will try to encourage researchers to resume work and research on Old English dry-point glosses by showing that this area has so far been neglected in scholarly research. To this end, four Old English dry-point gloss manuscripts that I have investigated will serve as examples to demonstrate the promising prospects of revitalising research on the Old English dry-point tradition.

\section{Old English Dry-Point Writing}

As on the Continent, Old English dry-point writing mainly occurred in the form of subsequently added entries, which can be divided into two groups according to their relation to the base text of the respective manuscript: additions with reference to the base text (scholia, glosses) on the one hand and unrelated additions to it - micro-texts in the stricter sense - on the other hand. No texts of any sizeable length in dry-point writing are extant (Studer-Joho 2017: 30): the Old English

2 There is no agreement in the scholarly discussion on textuality whether glosses constitute independent texts. Using a pragmatic or a communication-orientated text concept, one can consider glosses to fulfill the conditions of a text. See the detailed treatment in Schiegg (2015: 47-59). 3 Cf. Glaser and Nievergelt (2009: I, 228). Stylus glossing has a similarly high importance in the research of ancient Japanese and Korean languages. Japanese dry-point glosses ('kakuhitsuten') in sacred texts date back to the Nara period (710-784). The discovery of Korean stylus-glossed texts in 2000 has paved the way for a new evolutionary theory of glossing practices ('kundoku') in the Sinosphere. See Kobayashi (2004: 260, 353 and passim) and Kosukegawa (2014). 
dry-point corpus only consists of a few minuscule texts, ${ }^{4}$ glosses, corrections of English texts, ${ }^{5}$ personal names, ${ }^{6}$ 'probationes' and scribbles.

Glosses form the lion's share of the Old English dry-point tradition: we know of about 3,850 edited Old English dry-point glosses (Studer-Joho 2017: 269). The above-mentioned significance of dry-point glossing is considered essential also for the history of Old English. Some Anglo-Saxon manuscripts contain dry-point writing in Old English, which is generally ranked among the oldest original witnesses of the language. In the case of the Würzburg Isidore manuscript (Würzburg, Universitätsbibliothek, M.p.th.f.79), for example, glosses date from the middle of the eighth century (Hofmann 1963: 58), and in the 'Maihingen Gospels' (Augsburg, Universitätsbibliothek, Cod. I.2.4²) the dry-point glosses may even be dated to the first half of the eighth century (Hofmann 1963: 32).

\section{Research on Old English Dry-Point Glosses: Current State and Perspectives}

All in all, 1,291 manuscripts and manuscript fragments that are either of AngloSaxon origin or of Anglo-Saxon provenance before the year 1100 have been identified so far (Gneuss and Lapidge 2014: x). Studer-Joho's Catalogue describes 34 manuscripts known to contain Old English dry-point glosses. ${ }^{7}$ The relevant

\footnotetext{
4 We know of only very few scratched Old English texts. One example is the short text in Cambridge, Corpus Christi College, 57 on fol. 32v (Page 1979: 30; Studer-Joho 2017: 105). For other examples, also runic ones, see Studer-Joho (2017: 38-40).

5 Dry-point annotations added to the Old English text of Bede's Ecclesiastical History in Oxford, Corpus Christi College, 279.B, Part II, were detected and edited by Christine Wallis (2013). See also Studer-Joho (2017: 45-46).

6 Scratched personal names often form part of name-lists as for example in libri vitae and obituaria. Moreover, manuscripts feature dry-point names on the margins, such as an entry in Insular dry-point writing on a margin in London, British Library, Cotton Caligula A.xv; see CLA II, no.183. 7 That is also the actual number of manuscripts today (as of October 2018), despite two substantial modifications: one manuscript (Studer-Joho 2017: no. 32) was found not to be an Old English but an Old High German gloss manuscript (see further below, Section 4.2.4). One manuscript has been overlooked: [Rome], Città del Vaticano, Biblioteca Apostolica Vaticana, Pal. lat. 235, fols. 4-29 (Northumbria, s. viii in., Paulinus of Nola, Carmina natalitia; see Gneuss and Lapidge 2014: 658, no. 910), contains numerous dry-point annotations, mostly Latin glosses, corrections or technical signs, including one Old English dry-point gloss on fol. 24r/9, cementa : -i.clamas (Brown and Mackay 1988: 20-21). As may be suspected from the digitized image (http:// bibliotheca-laureshamensis-digital.de/bav/bav_pal_lat_235 [last accessed 20 March 2019]), further undeciphered glosses might also be Old English (e.g. fol. 9vb/10, above cessit, fol. 11rb/22,
} 
question is whether that is a lot or not. In order to assess this problem, we will take a look at the Old High German sources. Even though we know that there are differences between the tradition and survival of Old English glosses and the Old High German material in general (losses of manuscripts, different relationships between texts and glosses, etc.), it is still worthwhile to make a comparison of the data.

230 manuscripts are known to contain Old High German glosses. ${ }^{8}$ That is obviously more than 34 , but that is not the point. The crux of the matter is that about twenty years ago, 34 Old English and - only - 70 Old High German drypoint gloss manuscripts were known. The number of known Old High German dry-point gloss manuscripts has since been trebled (cf. Nievergelt 2017: 126 and Studer-Joho 2017: 54). This is the result of a systematic examination of collections of manuscripts with the aim of discovering and deciphering dry-point material. The glosses of about 150 manuscripts have only been found because they were particularly looked for. Such investigations were carried out also within Old English glossography - by Napier, Meritt, Bischoff and Hofmann, Page, Gwara, Morrison and Rusche (Studer-Joho 2017: 66-79). However, over the last twenty years such studies have largely been lacking.

If we consider the statements of scholars who have worked on Old English dry-point glosses and who repeatedly claim that there are many more unknown dry-point glosses yet to be found, ${ }^{9}$ the number of 34 Old English dry-point gloss manuscripts can be seen as highly provisional. ${ }^{10}$

As stated above, finding dry-point glosses requires systematic and patient examination of manuscripts. For the Old English glosses, pertinent studies of the above-mentioned scholars ${ }^{11}$ have shown how successful such an approach can be. In fact, there are two strong reasons for hoping that more glosses will eventually become known, once the search for them is intensified.

above usurpans, fol. 19ra/13, above uestibus, fol. 24r/4, above laxis; cf. Brown and Mackay 1988: 15). Scratched text can be seen in the lower margin of fol. $25 \mathrm{v}$. After consultation with Dieter Studer-Joho, this additional manuscript should be counted as no. 35 of Studer-Joho (2017).

8 See the permanently updated list in the "Althochdeutsche Glossen Wiki" $<$ https://glossenwiki. phil.uni-augsburg.de/wiki> [last accessed 20 March 2019]; cf. also BStK Online <https://glossen. germ-ling.uni-bamberg.de> under the category “Aktuelles” [last accessed 20 March 2019].

9 See the compilation of statements in Studer-Joho (2017: 14), to which his own statement can be added: "[...] the domain of dry-point glossing is the most likely candidate for the discovery of as yet unknown sizable quantities of OE material” (Studer-Joho 2017: 249).

10 In the words of Studer-Joho (2017: 252): "It is hard to believe that the known corpus of OE drypoint gloss MSS by pure chance represents the actual corpus of surviving OE dry-point gloss MSS". 11 See the detailed history of the study of Old English dry-point glosses in Studer-Joho (2017: 63-83, ch. 3). 
First, in most cases, when re-investigating manuscripts known to contain dry-point glosses, further glosses were found. The developments in Old High German glossography show that manuscripts that have been studied extensively can, if newly examined, yield previously unnoticed dry-point glosses in quite astonishing quantities. I mention some impressive examples of re-investigated manuscripts (Basel, Universitätsbibliothek, F.III.15c; Munich, Bayerische Staatsbibliothek, clm 4614, 6300, 14379), giving the old and the newly obtained data on the Old High German dry-point glosses contained in them: ${ }^{12}$

\begin{tabular}{lrr}
\hline Manuscript & Old no. of dry-point glosses & Current no. of dry-point glosses \\
\hline Basel, UB, F.III.15C & 38 & c. 200 \\
\hline Munich, BSB, clm 4614 & 50 & over 1,000 \\
\hline Munich, BSB, clm 6300 & 259 & 370 \\
\hline Munich, BSB, clm 14379 & 92 & 225 \\
\hline
\end{tabular}

The reason why these numbers differ is definitely not due to a lack of competence on the side of the earlier researchers - on the contrary: their outstanding pioneering achievements cannot be overvalued. But obviously they underestimated the expenditure of time for their work. Similar conditions such as in the research of Old High German can also be expected for Old English dry-point gloss manuscripts.

Second, it seems that Anglo-Saxon manuscripts have in large parts not yet been investigated systematically with a focus on dry-point material (cf. Studer-Joho 2017: 251-252). However, how could this problem be tackled? Where should we start? The investigation of an individual collection of partly related manuscripts seems to be a promising starting point. With regard to Old High German, the example of the St Gall manuscripts shows how fruitful this can be. In the older research literature (until about the year 2000), St Gall was considered a place where glossing with a stylus was not common practice - in complete contrast to the Bavarian monasteries with Old High German writing traditions such as Freising and Regensburg. Only three St Gall manuscripts were known to contain scratched glosses (cf. Glaser 1996: 56, 65). A systematic examination of the holdings has brought to light, however, that over 55 St Gall manuscripts contain Old High German dry-point glosses, over two thirds of them having not been known to be manuscripts glossed in Old High German. As regards Old English glossography, Josef Hofmann carried out a comparable project on the manuscripts

12 See the particular paragraphs in BStK and BStK Online (BStK no. 31(I+II), 488, 523, 576). 
of Anglo-Saxon-influenced Würzburg and other manuscripts connected to St Boniface's mission to Germany (Hofmann 1963: 27-65; cf. Studer-Joho 2017: 71). The last example also has shown that systematic research of manuscripts from common areas of tradition and influence can be regarded as a solution-orientated experimental approach.

\section{Towards a Revival of Research on Old English Dry-Point Glosses}

\subsection{A Promising Starting Point}

As mentioned above, it is now a good time to revive research on Old English drypoint glosses since we have come into possession of new reference works, which can be used as starting points for a revival of Old English dry-point research. For manuscripts, I should first mention the Handlist of Helmut Gneuss and Michael Lapidge (2014), a comprehensive bibliographical catalogue of Anglo-Saxon manuscripts up to 1100 . The book represents the culmination of a research work which Gneuss started 65 years ago, when he was a research student at St John's College, Cambridge, and which he completed together with many researchers over a long period of time (Gneuss and Lapidge 2014: ix-xii). The fundamental Katalog of Bernhard Bischoff (1998, 2004, 2014), another indispensable aid, was prepared, edited and rounded out with an index volume by Birgit Ebersperger (Bischoff 2017).

Furthermore, I would like to point to new reference works in the field of glosses. The publications by Rolf Bergmann and Stefanie Stricker (BStK, BStK Online, and Bergmann and Stricker 2009) may serve as comprehensive guides. Here the research of dry-point glosses is taken into account very carefully. Concerning glosses in general, recent studies have set new standards in the analysis and editing of Latin and vernacular glosses (e.g. Lendinara et al. 2011, Cinato 2015, Schiegg 2015, Blom 2017). Ever more assistance, also in the field of glosses, is provided by online dictionaries, for English glosses notably by the DOE. Relevant research projects such as Marginal Scholarship (<www.huygens.knaw.nl/ marginal-scholarship >) are currently underway.

For Old English dry-point glosses the first study deserving special mention is the new Catalogue of Studer-Joho (2017). For the first time, all Old English drypoint gloss manuscripts are presented together, the history of their exploration is reviewed and the corpus and its glosses are characterised with regard to their 
origins and dates of manuscripts, glossed texts, co-occurrence with other glosses, etc. Other, more detailed information has to be collected from different sources. Researchers have repeatedly pointed to undeciphered dry-point glosses. Entries are of particular interest in manuscripts known to contain the oldest Old English dry-point material, such as manuscripts Augsburg, Universitätsbibliothek, Cod. I.2.4² ('Maihingen Gospels'), ${ }^{13}$ Fulda, Hochschul- und Landesbibliothek, Bonifatianus $2^{14}$ and Würzburg, Universitätsbibliothek, M.p.th.f.79 (see below, Section 4.2.3). Moreover, researchers provide us with numerous references to legible but not edited glosses. Examples are glosses in manuscripts such as London, British Library, Cotton Cleopatra C.viii ${ }^{15}$ and Cambridge, University Library, Kk.3.21. ${ }^{16}$ With reference to London, British Library, Cotton Tiberius C.ii, Royal 13.A.xv and Cotton Vespasian D.xiv, Toon (1985: 320-321) estimates that there are many more dry-point glosses to be found and deciphered. Unfortunately, this material has still not been published (Studer-Joho 2017: 250-252). As the discussion following my paper at the symposium in honour of Helmut Gneuss in Munich has shown, some attempts have been made to prove Toon's claims and there are some doubts that he is right in predicting so many glosses to be read. Precisely therefore it is important that the respective manuscripts are examined anew and that the results are published.

Regarding potentially new Old English dry-point gloss manuscripts, research of Old High German - using dating, localization, content, etc. - has revealed that it is still impossible to develop methods that serve as reliable indicators for the discovery of manuscripts glossed with a stylus (cf. Nievergelt 2015: 334). Although we cannot make accurate projections, ${ }^{17}$ we can nevertheless look for evidence of certain relationships, e.g. within a library holding of manuscripts of similar age and/or within particular contexts that show a shared origin of glosses. Moreover, to discover new dry-point glosses, one might also look for manuscripts containing Old English ink glosses, since we know from Old High German gloss manuscripts that ink and dry-point glosses often occur together. Many manuscripts

13 The manuscript was probably written in Echternach in the first third of the eighth century and so were some of the Old English glosses. Apart from the edited glosses, the manuscript contains one further Old English dry-point gloss. Undeciphered entries may also be Old English. Cf. Studer-Joho (2017: 96-97) and Nievergelt (2019: 29 n. 75).

14 According to Hofmann (1963: 53-54), Fulda, Hochschul- und Landesbibliothek, Bonifatianus 2, contains numerous undeciphered dry-point traces.

15 Napier (1900: xxi) mentioned dry-point glosses, but did not edit them; see Studer-Joho (2017: 148).

16 Rusche (1994: 203) points to "a large amount” of still unpublished dry-point glosses, "many of which are clearly visible”; see Studer-Joho (2017: 132).

17 We have no direct proof that glosses in related manuscripts are also related to each other. 
with Old English ink glosses have not systematically been searched for dry-point material. Apart from that the mere fact that dry-point glosses may emerge everywhere should give us hope.

\subsection{Restarting the Work on Old English Dry-Point Glosses}

Studer-Joho (2017) shows the work that has to be done:

1. an investigation of known but unedited dry-point glosses;

2. an investigation of known but not yet deciphered glosses;

3. an investigation of manuscripts known to contain Old English dry-point glosses, in search of additional findings;

4. an investigation of Anglo-Saxon manuscripts not searched for dry-point material so far.

These are surely the central desiderata and they entail a lot of work.

I see my main task here in showing that even small attempts can lead to substantial corrections or additions in the overall picture. In the following, I use a selection of tests which I have undertaken recently in examining four Old English dry-point gloss manuscripts ${ }^{18}$ in order to demonstrate that Old English scratched glosses can still be found and deciphered (Sections 4.2.1-4.2.3). Unexpectedly, the investigation of one of these sources led me to a completely new assessment of its scratched glosses (Section 4.2.4).

\subsubsection{Paris, Bibliothèque nationale de France, lat. 9561}

Manuscript Paris, BnF, lat. 9561 (England, first half or around the middle of the eighth century; Gregory the Great, Regula pastoralis; Gneuss and Lapidge 2014: no. 894; Studer-Joho 2017: no. 30) was known to contain about 77 Old English dry-point glosses and further undeciphered entries. The glosses were first noted in CLA V, 590. In 1957, Meritt (1957) published 67 glosses, in 1987 Morrison (1987) another 10 glosses, thereby correcting some of Meritt's readings. Both authors pointed to further glosses they could not decipher.

The manuscript and its glosses were re-investigated and analysed in 2016 by Helmut Gneuss and me. This new investigation yielded the following results:

18 I would like to warmly thank all the responsible persons in the Bibliothèque nationale de France, Paris, the Stiftsbibliothek St Gall, the Stiftsarchiv St Paul and the Universitätsbibliothek Würzburg for giving me access to the manuscripts and for their kind help. 
41 new glosses were found, 24 glosses not read until then were deciphered, 17 readings could be corrected and 19 further illegible glosses were noted. About 10 lexemes had not been recorded so far. All in all, the new number of glosses identified as Old English in Paris, BnF, lat. 9561 is $136 .{ }^{19} 23$ have still not been deciphered. Gneuss (in Gneuss and Nievergelt 2018: 373-376) provides a linguistic analysis of all the glosses for the first time, placing them in the tenth century and the Southeast of England.

\subsubsection{St Paul in Carinthia, Stiftsarchiv 2/1, fols. 21-42}

The manuscript St Paul, Stiftsarchiv, 2/1 (England, first half of the eighth century; Anonymus ad Cuimnanum, Expossitio Latinitatis; Gneuss and Lapidge 2014: no. 933; Studer-Joho 2017: no. 33) was examined anew by me in 2017. Up until then, it had been known to contain one eighth-century Old English dry-point gloss (Bischoff and Löfstedt 1992: viii, 1. 129, note on p. 19, 1. 77). A further gloss, probably Old English, could not be entirely deciphered. Bernhard Bischoff, who first detected the glosses, asked Helmut Gneuss in 1992 concerning the second gloss what word the gloss could represent (Bischoff and Löfstedt 1992: viii and n. 4). Gneuss' answer - he suspected the Old English verb peccan in the controversial meaning 'to wrap into flames' - is confirmed by the renewed check of the gloss, read as dae ce?to (Figure 1). Moreover, an additional Old English gloss can be added here. The gloss on fol. 39vb/10 above foro, read by Bischoff as oregi (ibid.: viii, 135 n. on 19,324), was deciphered and identified as borigo: 1st pers. sg. ind. pres. of the weak verb OE borian 'to bore into, to bore through' (DOE s.v.; see also BT s.v.). The other dry-point entries seem to be Latin. ${ }^{20}$

\subsubsection{Würzburg, Universitätsbibliothek, M.p.th.f.79}

The codex (from Southern England or Mercia, first half of the eighth century; Isidore, Synonyma; Gneuss and Lapidge 2014: no. 946; Studer-Joho 2017: no. 34) is

19 Note for this number that some of the glosses form short syntagmata. In our count, they are treated as one gloss, whereas Meritt split them into several glosses.

20 For the Latin scratched glosses and some of the dry-point corrections in the manuscript, see Bischoff and Löfstedt (1992: viii, 94, 95, 120, 135 n. on 13,248; 13,285; 18,61; 19,299). Further Latin scratched glosses can be seen on fol. 23va/7, above periphrasin $(1,486)$ : contrarit [...], fol. 23va/10, above cubile $(1,488)$ : lectum, fol. 31ra/4, above conpaginari $(10,176)$ : consur[...], fol. 33va/21, adhibitae $(13,58)$ : dicte. Numerous other entries could not be deciphered. 


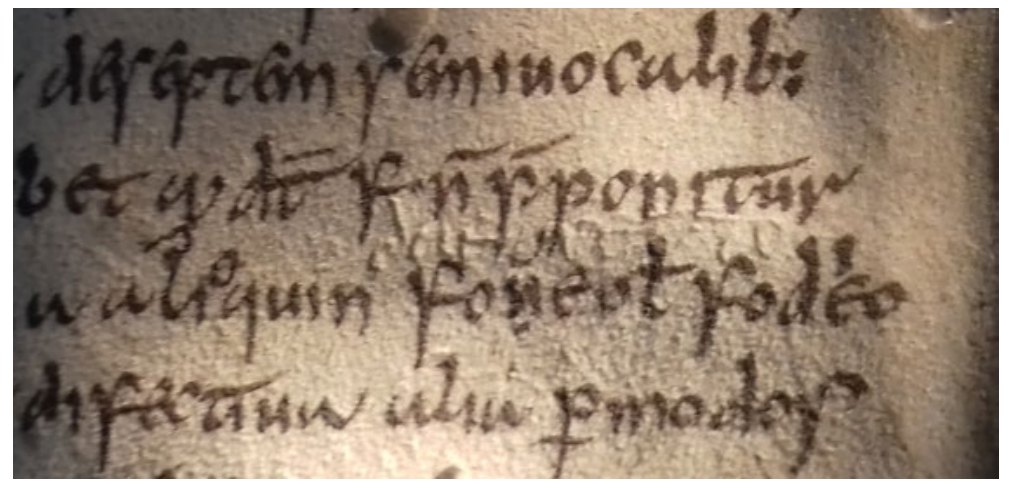

Figure 1: St Paul in Carinthia, Stiftsarchiv 2/1, fol. 39vb/9, an Old English scratched gloss dae ce?to above foueo. Photograph: Andreas Nievergelt. (c) Stiftsarchiv St Paul (with kind permission).

known to contain some of the very oldest witnesses of Old English, archaic-looking dry-point glosses from the middle of the eighth century (Hofmann 1963: 58). I examined the manuscript in 2017. Here too, some more Old English dry-point glosses were found. One of the original glosses can be seen on fol. $9 \mathrm{v} / 1$, above perpensum: INGETEHAD, probably part. pret. of the weak verb OE inteohhian 'to consider carefully' (cf. OE teohhian 'to consider'; BT s.v.). Some additional drypoint glosses have been entered by a later hand: fol. 4v/9, ex : of; fol. 5v/1, ad: te; fol. $14 \mathrm{v} / 3$, succurre : help. The numerous undeciphered dry-point entries in this manuscript deserve a new and thorough analysis. See the list given by Hofmann (1963: 65), which should be extended by further unidentified entries. ${ }^{21}$

\subsubsection{St Gall, Stiftsbibliothek, 1394, IX (p. 121-122, 125-128)}

The manuscript (Germany, eighth century; Aldhelm, De metris et enigmatibus; Studer-Joho 2017: no. 32; BStK: no. 255 [IV]) is preserved only in a few fragments. The dry-point glosses are written in an Anglo-Saxon minuscule of the same type as the script of the text. Almost all of them were erased later and are very hard to read today. In 1961, Meritt edited two glosses and determined the language as Old English (Meritt 1961: 441). Since then the manuscript has been considered an Old English dry-point gloss manuscript. However, when investigating the damaged

21 Further undeciphered glosses can for example be seen on fol. 8v/12, telis; fol. 8v/20, equum; fol. $11 \mathrm{v} / 9$, denegatur; fol. $15 \mathrm{v} / 7$, in te recta; fol. $15 \mathrm{v} / 12$, conuersationem, and many more. 
glosses, I discovered - to my surprise - that they were all not written in Old English but in Old High German, as can be seen from glosses such as p. 128a/14, roscida : naza. Perhaps the dialect of the glosses represents the local dialect of the "German centre with Anglo-Saxon traditions" (CLA VII, 982), where the manuscript was written. Thus the glosses can even tell us something about the origin of the manuscript. This last example shows that in the case of problematic glosses even the linguistic attribution may have to be revised.

\section{Conclusion}

These four examples (Sections 4.2.1 - 4.2.4) serve to illustrate the situation of the sources and the current state of research. In view of what remains to be done, renewed scholarly interest in scratched glosses, their detection, analysis and interpretation turns out to be a clear desideratum. I hope to have succeeded in showing how promising research into the Old English dry-point tradition can be. This approach can be perceived as an integral part of comprehensive research of Old English micro-texts.

\section{Works Cited}

Bergmann, Rolf and Stefanie Stricker (eds.). 2009. Die althochdeutsche und altsächsische Glossographie: Ein Handbuch. 2 vols. Berlin: De Gruyter.

"Bibliotheca Laureshamensis digital”. Virtuelle Klosterbibliothek Lorsch. <http://bibliothecalaureshamensis-digital.de> [last accessed 20 March 2019].

Bischoff, Bernhard and Bengt Löfstedt (eds.). 1992. Anonymus ad Cuimnanum: Expossitio Latinitatis. CCSL 133 D. Turnhout: Brepols.

Bischoff, Bernhard. 1998. Katalog der festländischen Handschriften des neunten Jahrhunderts (mit Ausnahme der wisigotischen). Volume 1: Aachen - Lambach. Wiesbaden: Harrassowitz.

Bischoff, Bernhard. 2004. Katalog der festländischen Handschriften des neunten Jahrhunderts (mit Ausnahme der wisigotischen). Volume 2: Laon - Paderborn. Ed. Birgit Ebersperger. Wiesbaden: Harrassowitz.

Bischoff, Bernhard. 2014. Katalog der festländischen Handschriften des neunten Jahrhunderts (mit Ausnahme der wisigotischen). Volume 3: Padua - Zwickau. Aus dem Nachlass herausgegeben von Birgit Ebersperger. Wiesbaden: Harrassowitz.

Bischoff, Bernhard. 2017. Katalog der festländischen Handschriften des neunten Jahrhunderts (mit Ausnahme der wisigotischen). Volume 4: Gesamtregister. Ed. Birgit Ebersperger. Wiesbaden: Harrassowitz.

Blom, Alderik H. 2017. Glossing the Psalms: The Emergence of the Written Vernaculars in Western Europe from the Seventh to the Twelfth Centuries. Berlin: De Gruyter. 
Brown, Thomas J. and Thomas W. Mackay. 1988. Codex Vaticanus Palatinus Latinus 235: An Early Insular Manuscript of Paulinus of Nola Carmina. Turnhout: Brepols.

BStK = Bergmann, Rolf and Stefanie Stricker (eds.). 2005. Katalog der althochdeutschen und altsächsischen Glossenhandschriften. 6 vols. Berlin: De Gruyter.

BStK Online = "Ahd. und as. Glossenhandschriftendatenbank". Universität Bamberg. <https:// glossen.germ-ling.uni-bamberg.de> [last accessed 20 March2019].

BT = Bosworth, Joseph and T. Northcote Toller (eds.). 1882-1898. An Anglo-Saxon Dictionary. Based on the Manuscript Collections of the Late Joseph Bosworth. London: Oxford University Press. Supplement by T. Northcote Toller. 1921. Oxford: Clarendon.

Cinato, Franck. 2015. Priscien glosé: L'Ars grammatica de Priscien vue à travers les gloses carolingiennes. Turnhout: Brepols.

CLA = Lowe, Elias A. (ed.). 1934-1971. Codices Latini Antiquiores: A Paleographical Guide to Latin Manuscripts Prior to the Ninth Century. 12 vols. Oxford: Clarendon.

$D O E=$ Dictionary of Old English, $A$ to I. 2018. Ed. Angus Cameron, Ashley Crandell Amos, Antonette diPaolo Healey et al. Toronto: Dictionary of Old English Project. <http://www. doe.utoronto.ca> [last accessed 20 March 2019].

Glaser, Elvira. 1996. Frühe Griffelglossierung aus Freising: Ein Beitrag zu den Anfängen althochdeutscher Schriftlichkeit. Göttingen: Vandenhoeck \& Ruprecht.

Glaser, Elvira and Andreas Nievergelt. 2009. "Griffelglossen”. In: Rolf Bergmann and Stefanie Stricker (eds.). Die althochdeutsche und altsächsische Glossographie: Ein Handbuch. 2 vols. Berlin: De Gruyter. I, 202-229.

Gneuss, Helmut and Michael Lapidge. 2014. Anglo-Saxon Manuscripts: A Bibliographical Handlist of Manuscripts and Manuscript Fragments Written or Owned in England up to 1100. Toronto: University of Toronto Press.

Gneuss, Helmut and Andreas Nievergelt. 2018. "The Old English Dry-Point Glosses in Paris, BnF MS. Lat. 9561”. In: Claudia Di Sciacca, Concetta Giliberto, Carmela Rizzo and Loredana Teresi (eds.). Studies on Late Antique and Medieval Germanic Glossography and Lexicography in Honour of Patrizia Lendinara. 2 vols. Pisa: ETS. 351-376.

Hofmann, Josef. 1963. "Altenglische und althochdeutsche Glossen aus Würzburg und dem weiteren angelsächsischen Missionsgebiet”. Beiträge zur Geschichte der deutschen Sprache und Literatur 85: 27-131.

Kobayashi, Yoshinori. 2004. Kakuhitsu bunken kenkyū dōron - jōkan higashi Ajia hen. Tokyo: Kyūko.

Kosukegawa, Teiji. 2014. “Explaining what Kundoku Is in the Premodern Sinosphere”. Histoire Epistémologie Langage, dossier 7. <https://dossierhel.hypotheses.org/257> [last accessed 20 March 2019].

Lendinara, Patrizia, Loredana Lazzari and Claudia Di Sciacca (eds.). 2011. Rethinking and Recontextualizing Glosses: New Perspectives in the Study of Late Anglo-Saxon Glossography. Porto: Fédération Internationale des Instituts d’Études Médiévales.

Meritt, Herbert D. 1957. “Old English Glosses to Gregory, Ambrose and Prudentius”. Journal of English and Germanic Philology 56: 65-68.

Meritt, Herbert D. 1961. “Old English Glosses, Mostly Dry Point”. Journal of English and Germanic Philology 60: 441-445.

Morrison, Stephen. 1987. “On some Noticed and Unnoticed Old English Scratched Glosses”. English Studies 68: 209-213.

Murdoch, Brian. 1983. Old High German Literature. Boston: Twayne.

Napier, Arthur S. (ed.). 1900. Old English Glosses: Chiefly Unpublished. Oxford: Clarendon. 
Nievergelt, Andreas. 2015. “Nachträge zu den althochdeutschen und altsächsischen Glossen (2014/15)". Sprachwissenschaft 40: 289-340.

Nievergelt, Andreas. 2017. "Nachträge zu den althochdeutschen und altsächsischen Glossen (2015/16)”. Sprachwissenschaft 42: 121-176.

Nievergelt, Andreas. 2019. Althochdeutsch in Runenschrift: Geheimschriftliche volkssprachige Griffelglossen. Zeitschrift für deutsches Altertum und deutsche Literatur. Beiheft 11 [2., aktualisierte und erweiterte Auflage]. Stuttgart: Hirzel.

Page, Raymond I. 1979. “More Old English Scratched Glosses”. Anglia 97: 27-45.

Rusche, Philip G. 1994. “Dry-Point Glosses to Aldhelm's De laudibus virginitatis in Beinecke 401". Anglo-Saxon England 23: 195-213.

Schiegg, Markus. 2015. Frühmittelalterliche Glossen: Ein Beitrag zur Funktionalität und Kontextualität mittelalterlicher Schriftlichkeit. Heidelberg: Winter.

Studer-Joho, Dieter. 2017. A Catalogue of Manuscripts Known to Contain Old English Dry-Point Glosses. Tübingen: Narr Francke Attempto.

Toon, Thomas E. 1985. "Preliminaries to the Linguistic Analysis of Old English Glosses and Glossaries”. In: Roger Eaton, Olga Fischer, Willem F. Koopman and Frederike van der Leek (eds.). Papers from the 4th International Conference on English Historical Linguistics: Amsterdam, 10-13 April, 1985. Amsterdam: Benjamins. 319-329.

Wallis, Christine. 2013. "Layers of Reading in the Old English Bede: The Case of Oxford Corpus Christi College 279B". In: Andreas H. Jucker, Daniela Landert, Annina Seiler and Nicole Studer-Joho (eds.). Meaning in the History of English: Words and Texts in Context. Amsterdam: Benjamins. 19-38.

Whitman, John, Miyoung Oh, Jinho Park, Valerio L. Alberizzi, Masayuki Tsukimoto, Teiji Kosukegawa and Tomokazu Takada. 2010. "Toward an International Vocabulary for Research on Vernacular Readings of Chinese Texts (漢文訓讀 Hanwen Xundu)”. SCRIPTA 2: 1-36. 
Bereitgestellt von | UZH Hauptbibliothek / Zentralbibliothek Zürich 